\section{Small increase brings big gains}

Tokyo

OVERALl support for academic research in Japan will not keep pace with inflation this year, according to the 1986 budget figures of the Ministry of Education, Culture and Science. The ministry is by far the largest public source of support for basic research in the universities, but it has won only a tiny overall rise (less than one per cent) in funds for the direct support of research and international exchange.

The ministry's figures compare badly with the boom in spending on research by industry, a boom that puts Japan second only to the United States in total research spending in the non-communist world. The root of the problem lies in the high priority given by the government to tack-

\begin{tabular}{lrr}
\hline Japan's science budget (contd) \\
Ministry of Education, & $\begin{array}{r}\text { Yen } \\
\text { (thousand } \\
\text { million) }\end{array}$ & $\begin{array}{r}\text { Percentage } \\
\text { increase or } \\
\text { decrease }\end{array}$ \\
Culture and Science & 43.5 & +3.5 \\
Grants in aid of research & & \\
Maintence of scientific & 7.8 & +36.8 \\
$\quad$ research system & 0.8 & +41.7 \\
Research fellowships & 20.8 & -25.2 \\
Energy research & $(8.2)$ & $(+9.2)$ \\
$\quad$ Nuclear fusion) & $(5.9)$ & $(-58.2)$ \\
$\quad$ Accelerator physics) & 12.4 & +12.9 \\
Space research & 0.5 & +41.8 \\
Marine science & 2.0 & +1.0 \\
Earth science & 3.1 & -7.1 \\
Polar research & 1.8 & +6.0 \\
Cancer research & & \\
International academic & 3.7 & +1.9 \\
$\quad$ exchange & & \\
International student & 11.7 & +16.2 \\
$\quad$ exchange & & \\
\hline
\end{tabular}

ling the ever-increasing budget deficit and the austere budgets this makes necessary.

Although little has been gained overall, there are some bright spots. Direct grantsin-aid of research are up by 3.57 per cent, an annual rate of growth that has been fairly constant over the past four years, and which is ahead of the rate of inflation (about two per cent during the same period). Overall, 15,000 grants were given out, from 53,000 applicants.

Big grants tend to fall into two categories: those for "special distinguished research" likely to produce outstanding results recognized internationally, and those for "special research". The latter is an unusual category in that it is awarded to a field rather than to an individual; researchers all over Japan may apply to participate in such a project. Both types of grants go to scientists at the leading edge of research and their topics give a good idea of what are perceived as the hottest areas. As elsewhere, molecular biology and semiconductor physics are currently among the winners.

Among the 13 special research projects (total cost Y5.3 thousand million, US $\$ 26.5$ million) beginning this year are those on the regulation of complex genetic systems and their responses to stresses in the intracellular and extracellular environment, the physiology of blood vessel endothelial and smooth muscle cells and changes in arteriosclerosis, biologically active substances studied through chemical synthesis and the development of biosensors in the "special distinguished" category, projects (total funding Y2.3 thousand million) have recently begun on semiconductor superlattice surface structure, the quantum Hall effect and compound semiconductor/insulator interface physics. On the biological side are those on B-lymphocyte multiplication and differentiation, the mechanism of division of animal cells, the regulation of vasoactive peptide synthesis, the regulation of enzyme synthesis in higher animals and a new protein synthesis system.

Overall, though, there has been no increase in total support for these top grants. The increase in grants-in-aid is concentrated in the smallest category of grants (up to Y3 million) available for individual projects, the small grants (up to Y1.2 million) available for researchers under 37 and the grants for cooperative research between different institutes.

Extra money has gone towards strengthening the "scientific research system" (up 36.8 per cent). Most of the increase goes towards a restructuring of the Tokyo University bibliography centre as a nationwide scientific information centre.

There is also a big increase in funds for postdoctoral fellowships, although the
The Communist Party of the Soviet republic of Kirgizia has accused the Kirgiz Academy of Sciences of "serious failings". Addressing the Party Congress last month, the First Secretary of the Kirgiz Party, Absamat Masaliev, accused the academy of publicizing even routine and insignificant developments as major breakthroughs, and even reporting research work that had not been done at all. At the previous party congress, five years ago, the president of the academy, Murzabek Imanaliev, had claimed that its scientists had, "for the first time anywhere", obtained "natural iron powders, alloyed with rare earth elements", and had established with industry a semi-pilot plant for the production of such powders. This claim, Masaliev said, was simply wishful thinking.

To bolster such claims, Masaliev continued, the Kirgiz academicians have spent considerable sums on organizing symposia and conferences, and have bolstered their prestige with lavishly furnished offices. Yet the scientific standard of the Kirgiz original amount being spent was not large.

Many of the increases are being paid for by cuts in the budget for energy research including a huge reduction in funding ( -58.2 per cent) for the TRISTAN project, the construction of an electronpositron collider ring at the Institute of High-Energy Physics in Tsukuba Science City. The ring is now almost complete and will be commissioned in November, at energies around $23-25 \mathrm{GeV}$. With the addition of superconducting cavities, it should be possible to reach $36 \mathrm{GeV}$, but plans to turn the whole ring into an electron-proton collider have virtually been abandoned.

One ambitious project that does seem likely to bear fruit is the scheme developed by the Institute of Space and Astronautical Science (ISAS) designed to put a satellite into orbit around the Moon. Following the success (so far) of the first deep-space launch that sent the satellite Suisei towards a March encounter with Halley's comet, funds have been obtained to work on a prototype for a Moon launch (see Nature 315, 173; 1985) in the early 1990s.

Another ISAS project will be supported from the funds set aside for international cooperation - several years of discussion with Chinese scientists have resulted in a high-altitude balloon launch programme which begins with a maiden flight in July.

Marine science also seems to receive a boost $(+41.8$ per cent $)$. But most of this is to pay for the expensive business of full participation in the Ocean Drilling Program, even though the drill ship is not expected in Japanese waters until the 1990s.

Alun Anderson academy is so low, he said, that not a single institute or team has been included in the new "inter-branch" scientific-technical complexes now being established unionwide, as part of the "scientific-technological revolution".

This is not the first republic academy to be attacked for slackness in the run-up to the All-Union Party Congress later this month. A few weeks ago, the Uzbek academy was accused of nepotism and general slackness, attributed to the prolonged illness of its president, who has since been replaced.

But the charge of falsifying research claims is far more serious. It is standard Soviet practice to embark on a major shake-up or purge by selecting a few smaller bodies as examples, thus giving more important institutions a chance to put their affairs in order without public censure. Indications are that the programme of reforms launched by Mr Gorbachev is taking a close look at research as well as the administrative sector. 